\title{
Can Turkey Implement Malaysian Takaful Know-How into Turkish Market? A Qualitative Inquiry ${ }^{1}$
}

\author{
Hakan Aslan*
}

Emin $\mathrm{Avcl}^{* *}$

Received: 20.12 .2020

Accepted: 11.03.2021

DOI: $10.25272 /$ ijisef. 816143

Type: Research Article

\begin{abstract}
Even though takaful practices have around forty years of history globally, takaful operations are a comparatively new and underdeveloped sector in the Turkish insurance market. Given its dominant Muslim population, well-developed financial system, and the fact that takaful contributions have grown exponentially which is supported by current statistics, Turkey has great potential in prospering its takaful market. Thus, Turkey should develop further policies to develop its own takaful operators. In achieving so, Malaysia, which is considered to be one of the most advanced takaful ecosystems in the world, has been regarded as an example for comparison to probe into its takaful sector and evaluate the opinions of the Malaysian professionals towards the development of the takaful system in Turkey. In this paper, a phenomenological perspective has been used, assuming takaful as the phenomenon. This phenomenon was investigated by examining the experiences of five business professionals and four Shariah scholars through semi-structured interviews. With this technique, it is also aimed to obtain some valuable suggestions for the Turkish takaful industry. It is found that Turkey should firstly develop its regulatory and Shariah governance system and then take gradual steps to regulate to market. In addition, increasing awareness, developing qualified human capital, adapting technology for marketing, and standardising the market practices will help the development of the takaful market in Turkey.
\end{abstract}

Keywords: Takaful, Participation insurance, Islamic insurance, Islamic finance

Jel Codes: G22, Z12, G29

\footnotetext{
${ }^{1}$ This study is based on the Hakan Aslan's PhD thesis research, which is supervised by Prof. Dr. Emin Avcl, conducted at the Institute of Social Sciences, Marmara University, Istanbul, Turkey.

${ }^{*}$ Res. Asst. Dr., Research Center for Islamic Economics and Finance (ISEFAM), Sakarya University, hakanaslan@sakarya.edu.tr, ORCID: 0000-0003-2923-6837

** Prof. Dr., Department of Accounting and Finance, Faculty of Business Administration, Marmara University, eavci@marmara.edu.tr, ORCID: 0000-0003-3172-897X
} 


\section{Introduction}

The Islamic finance practices have existed for around 35 years in Turkey. Special Finance Houses (SFH) are generally accepted as the starting point of Turkey's Islamic financial services. Although, there had been different initiatives previous to the establishment of SFHs, these initiatives did not prolong in the market (Özdemir \& Aslan, 2018, p. 17). SFHs were structured as Islamic banks in 2005 by the Banking Law no.5411, which enabled SFHs to be recognised as banks globally. According to this law, SFHs are structured as participation banks (Yas et al., 2018). Participation banks are the main representative of the Islamic financial institutions (IFI) in Turkey. Moreover, takaful operators have started to come to prominence in the Islamic financial industry in Turkey.

Although, there had been several takaful practices since the end of 2009 (Aslan, 2015), there was neither specific regulations nor any single article in the Insurance Law no.5684 for the takaful companies in Turkey until the end of 2017. Ever since the issuance of the regulation, takaful operations have developed faster. Compared to the Islamic banking sector, takaful operations have proliferated in the last six years from 2014 to 2019, in terms of the gross written premiums/contributions. In 2014, the takaful sector accounted for only $1.48 \%$ of the market, with $1.67 \%$ for the non-life branch and $0.10 \%$ for the life branch. However, by 2019 , the total market share of the takaful sector has increased to $4.96 \%$, with $5.58 \%$ for the non-life branch and $1.81 \%$ for the life branch. In other words, the gross takaful contributions have increased for more than three times from 2014 to 2019. It is crucial to indicate that general takaful business has more resilient growth than the life branch in this period. For this reason, the share of the general takaful from the market is higher than the total market share. General takaful business is much stronger than family takaful. One of the reasons for this situation is that the Private Pension system has more incentives compared to life insurance business in Turkey. Moreover, it is worth mentioning that compared to the Islamic banking in the banking sector in Turkey, whose share fluctuates around $5 \%$ by asset size, takaful as an Islamic alternative to insurance is growing more solidly (TSB, 2019).

Malaysia is one of the pioneering countries in the takaful industry, where takaful practices have started since 1984 by the enactment of the Takaful Act. The development of the takaful system in Malaysia can be evaluated in the following four phases (Berkem, 2014, p. 1222; COMCEC, 2019, p. 62; Othman et al., 2017, p. 95).

The first phase of the takaful industry consists of the time between 1984 and 1992. In these years, there was only one Takaful Operator (TO) in Malaysia. This phase is the phase of building fundamental regulatory, supervisory, and Shariah guidelines for TOs that help them expedite their business operations. It is crucial to indicate that the regulatory and supervisory body, Bank Negara Malaysia (BNM), had a "lighter touch approach" to develop regulation. This manner helped the takaful sector to develop smoothly contrary to stricter principle and standard oriented approach (Berkem, 2014, p. 1222). 
The second phase covers the years from 1993 to 2000. This phase witnessed the development of retakaful operators and new market players for the sectors. In addition, the establishment of the Shariah Advisory Council by BNM, which is the central Shariah board of the country, was the most critical step for TOs regarding Shariah supervision and regulation.

The third phase started with introducing the Financial Sector Master Plan (FSMP) in 2001 where the fundamental objectives of the FSMP are "strengthening the regulatory and supervisory framework, developing a domestic financial infrastructure, enhancing competition and domestic capacity, and promoting shareholder and consumer activism" (COMCEC, 2016, p. 81). One of the aims of FSMP is to strengthen the role of Malaysia in the Islamic finance sector (Othman et al., 2017, p. 96). On the other hand, new takaful operators obtained their licences in this period. Nonetheless, the Malaysian Takaful Association (MTA) was established in 2002, aiming at increasing the cooperation among takaful industry players as well as the homogeneity in operations (COMCEC, 2019, p. 62). Also, they set a goal to achieve a 20\% share of the insurance market in Malaysia (Othman et al., 2017, p. 96).

Lastly, the fourth phase started with unveiling the Financial Sector Blueprint (FSB) in 2011, which consists of a period of 2011-2020. One of the focuses of this plan is to achieve the internationalisation of the Malaysian Islamic finance sector (Berkem, 2014, p. 1223). The most critical advancement was the enactment of the Islamic Financial Services Act (IFSA) in 2013, regarding regulation and supervision issues. Previously, the takaful sector was governed by the Takaful Act; however, IFSA unified the whole IFIs regulations under a single law. According to IFSA, takaful operators are no longer able to have composite business licences. This step is in line with the global insurance market practices where family and general takaful operations have different types of risks and maturity.

Compared to other countries, the Malaysian takaful industry is highly developed from several perspectives such as Shariah governance, regulatory and supervisory bodies, market penetration, awareness towards takaful products, skilful talents and academic research. However, there are still some challenges within the local market particularly similar to the global markets. E. Ismail \& Alhabshi (2017, p. 351) categorise those challenges as follows: developing regulations, awareness and perception, talent shortages, market competition, economic instability, and lack of retakaful capacity and Shariah-compliant investments. The similar challenges are also indicated in other studies as well (Alhabshi, 2017; COMCEC, 2019). Due to the challenges mentioned above, the Malaysian takaful industry still remains a great potential to perfect.

As it has been explained, takaful has great potential, and to reach its potential, Turkey seems to require making some changes. This study aims to answer whether Turkey can take Malaysia, which is the most advanced takaful ecosystem in the world (World Bank \& IDGB, 2016, p. 112), as an example country to learn from the experience for the development of the takaful system in Turkey. 


\section{Literature Review}

According to Islamic law, the conventional insurance system is not considered lawful due to its nature, which consists of gharar, maysir and riba (Rahman \& Redzuan, 2009). Takaful defines the insurance system of Islamic economic thought. Takaful is an Arabic word which means "guarantee, bail, or an act of securing one's need" (Ali \& Odierno, 2008). Technically takaful is the insurance system providing, ghararar, maysir and riba free alternative to the conventional insurance system.

There are very limited studies that have been conducted on the takaful system in Turkey. When we review the early literature about takaful in Turkish, we were unable to find studies that can be categorised into takaful studies, although there several early studies are focusing on insurance from an Islamic perspective (Dalg1n, 1994, 2003; Demir, 2002; Ünalan, 2008; Y1lmaz, 1997). As a result, there is a very significant gap in the literature with regard to takaful studies in Turkey.

The contemporary takaful studies started to be published in the mid-2010s. The first studies were provided with brief and superficial information regarding takaful and its development in the world (Çalık, 2014; Ölçen, 2014; Yıldırım, 2014). Some studies provided proposals for the development of the takaful system in Turkey (Aslan, 2015). Üstün (2014) indicated that takaful should be structured as a cooperative model, which would show the essence of cooperation. Ustaoğlu (2014) conducted a survey study of the understanding of attitudes towards takaful in Turkey. He found that the demands on takaful would increase with the level of public awareness. Meanwhile, he argued that people with religious sensitivities usually had low price elasticity. Aslan (2017), in his study, evaluated contemporary issues of the takaful market in the world. Additionally, he offered several proposals for the development of the Turkish takaful market, in which he specifically indicated the importance of the regulation and the Shariah supervision. Aslan \& Durmuş (2016) interviewed some takaful practitioners in their study to evaluate takaful practices in Turkey. They found that practitioners perceived that the demands for takaful would be positively affected if there was an increase in the level of public awareness, the establishment of a central Shariah board and the support of the authorities toward takaful. It is also crucial for the religious authority of Turkey to replace the current fatwa regarding insurance, a fatwa that grants permission to the conventional insurance and contradicts the Islamic belief, into a more suitable fatwa from the Islamic perspective on takaful. Moreover, Hacak (2017) indicated that there was not a big difference between takaful and the conventional insurance in his study. Hence, it is necessary to develop another theoretical approach to advance the takaful theory.

Some contemporary studies evaluate takaful regulations and takaful practices from different perspectives. Aksoy (2018) analysed the current practices from a legal perspective, while Ünlü (2018) provided some insight of tax issues regarding the surplus received by the takaful participants. Laçinbala \& Ünsal (2019) assessed the takaful window practices from several aspects. They indicated that although window practices were a controversial issue from the 
Shariah perspective, there were numerous advantages from a practical perspective. They suggested that Turkey should follow the practices of some other countries in a way that they should retain takaful windows till the takaful industry reached some level of density and public awareness.

In this study, we adopted qualitative study to investigate whether Malaysia can be a role model for takaful eco-system in Turkey. Qualitative analysis methods have been widely used in recent literature. Various qualitative studies have been conducted in the field of home financing (Loke Ke Wei \& Mohd Thas Thaker, 2017), Islamic banking (Ayedh \& Echchabi, 2015; Echchabi \& Abd Aziz, 2014), Islamic stock markets and derivatives (Jaiyeoba \& Haron, 2016; Sakti et al., 2016), and takaful (Faisal Nazir Hussain \& Noor, 2018; Mohammed et al., 2014; Mohd Fauzi \& Abdul Rashid, 2014; Noordin \& Fares, 2017). Different countries investigated by qualitative analysis, and most of these studies used semi-structured interviews. However, there is an important gap in the literature for the Turkish takaful market.

\section{Developing Research Questions}

Literature survey has helped to develop research questions for the qualitative part of this study. The main problems in the takaful sector, current status, and future expectations were the questions' main areas. The primary motivation for the qualitative analysis is to learn Malaysian takaful experience from professionals' point of view. The second motivation is to obtain suggestions from professionals for the takaful sector of the Turkish market. For this reason, 12 semi-structured questions were prepared for the interviews. Besides the last two questions, the first ten questions were asked to discover Malaysian takaful experience from those who have a significant role in the market. The main research questions of the study can be stated as follows:

RQ-1: How do Shariah scholars / business professionals evaluate the current development of the takaful system in Malaysia from regulatory, supervisory, and governance perspectives?

RQ-2: What is the role of agencies in the takaful sector? How Shariah scholars / business professionals you evaluate their knowledge and responsibility in the market?

RQ-3: What is the role of Shariah governance in the takaful ecosystem, and how does this system work in Malaysia? Are there any issues regarding Shariah incompliance?

RQ-4: What are the roles of government and regulatory \& supervisory bodies in the development of the takaful system?

RQ-5: Does awareness plays an important role in development? How Shariah scholars / business professionals you evaluate customers' awareness about takaful?

RQ-6: What is the role of financial markets in the development of the takaful system?

\section{Methodology}

Qualitative researchers frequently carry out a qualitative analysis when a lack of theory or an established theory does not sufficiently explain a phenomenon. Therefore, another significant 
aspect in a qualitative study is that the method is inductive; that is, researchers obtain evidence instead of deductively evaluating assumptions as positivist research to construct ideas, hypotheses, or theories. (Merriam \& Tisdell, 2016, p. 17).

Qualitative analysis is considered as complementing in the finance field (Burton, 2007). Qualitative research provides a superior and broad understanding of social science issues by attempting to explore what people say, write, and behave (Kaczynski et al., 2014, p. 128). It is considered an alternative broadening way of researching the field of finance by increasing empirical sources. For example, using the managers' experiences of the financial institutions may add value to research findings (Kaczynski et al., 2014). Some researchers even developed research strategies for future researchers who are willing to implement qualitative techniques in finance (Salmona et al., 2015). As discussed, qualitative and mixed method analysis techniques are becoming more important in finance.

When they are interested in investigating the significance, composition, and core of the living reality of real phenomena, researchers use the phenomenological method (Edmonds \& Kennedy, 2017, p. 168). Phenomenological studies focus on individual's experiences, which is the primary source for qualitative data in this method. It is expected from participants to focus on their experience on the phenomena (Christensen et al., 2015, p. 370). This part of the study comprises qualitative research that examines interviews conducted with business professionals and Shariah scholars from a phenomenological perspective. The main phenomenon in this study has been chosen to be takaful, and questions related to this phenomenon have been asked to participants. This perspective attempts to obtain information as much as possible regarding the phenomenon by using the experiences of individuals. In this study, participants were highly experienced business professionals and Shariah scholars. Details regarding qualitative analysis will be provided in the following subsections.

\subsection{Sample Selection}

Sample selection is the procedure of deciding where to obtain the data. There are various sampling methods. The fundamental distinction in sampling methods is based on whether the method is based on probability. Probability sampling enables the researcher to generalise study findings; for this reason, this method is used for quantitative analysis. On the other hand, qualitative research methods do not consist of probability-based sampling due to its purpose and structure. Since generalisation is neither required nor appropriate (Merriam \& Tisdell, 2016, p. 96; Ritchie \& Lewis, 2003, p. 78), a purposeful (in some sources called as purposive) sampling method is used for this study.

Purposeful sampling is based on the premise that the researcher needs to identify, understand, and obtain knowledge, and thus, must choose a sample from which to learn the most (Merriam \& Tisdell, 2016, p. 96). Qualitative studies aim to obtain a profound understanding from small sample sizes that makes purposeful sampling is the most appropriate method for the study (Leavy, 2017, p. 80). There are different ways of implementing purposeful sampling; however, 
criterion sampling is the widespread method (Edmonds \& Kennedy, 2017, p. 20), which is adopted in this study.

The initial aim of this study was the investigation of Malaysian takaful experience. For this reason, the first decision was made to choose the sample from different perspectives. Interviewees' selected according to their experience in the field and their current qualification as it has been practised in the literature (Md Zabri \& Mohammed, 2018). It is aimed to obtain experiences regarding Shariah issues from Shariah board members of the Malaysian takaful industry. On the other hand, business professionals are chosen to investigate the practitioners' perspective. The main criteria for the Shariah scholars to be chosen are to be a member of the Central Shariah Board of the BNM or one of the takaful operators. We decided to choose individuals holding a middle or higher level of manager position with at least ten years of experience in the takaful sector as a sample to represent business professionals. The snowballing technique was also used during sample selection. The first interviewee is asked whether they know anyone meeting this criterion. According to the provided information, in total, five high-level managers were interviewed. For Shariah scholars, data obtained from BNM and TOs websites. A total of six Shariah scholars have been contacted, but only four of them were able to conduct the interview. In the end, nine successful interviews were conducted.

Qualitative data sampling limitations do not have strict rules or calculation methods like quantitative data sampling. It is important to reach a satisfying amount of information from participants. This issue has been widely discussed from various researchers' perspectives, and it is concluded that the minimum required interview should be six for phenomenological studies (Guest et al., 2006). As a result of this, nine interviews were considered adequate for data saturation for this study. It has also been realised during interviews; receiving similar information happened.

\subsection{Interviewee Profiles}

Four Shariah scholars and five business professionals have been interviewed. Three of the Shariah scholars were serving as a member of the Shariah Advisory Council (SAC) of Bank Negara Malaysia, which is the highest Shariah authority for the Islamic finance industry in Malaysia, and the other scholar was serving as a Shariah advisory to takaful companies when the interview conducted. Brief details about Shariah scholars have given in Table 1 below. All of the Shariah scholars were also working as academic scholars in various universities. Due to providing the anonymity of the interviewees', the name of the institutions has not been provided. Shariah Scholars numbered between A-1 to A-4 as a reference for the following section. 
Table 1: Profile of the Shariah Scholars

\begin{tabular}{|l|l|l|l|}
\hline Number & Institutions & Education & Position \\
\hline A-1 & $\begin{array}{l}\text { BNM \& } \\
\text { University }\end{array}$ & MA in Shariah & SAC Member, Academician \\
\hline A-2 & $\begin{array}{l}\text { BNM \& } \\
\text { University }\end{array}$ & PhD in Shariah & SAC Member, Academician \\
\hline A-3 & $\begin{array}{l}\text { BNM \& } \\
\text { University }\end{array}$ & $\begin{array}{l}\text { PhD in Law, MA in } \\
\text { Shariah }\end{array}$ & SAC Member, Academician \\
\hline A-4 & TO \& University & PhD in Shariah & Shariah Advisor, Academician \\
\hline
\end{tabular}

Table 2 shows the profile of the interviewed business professionals from the takaful sector. All of the interviewees have more than 20 years' experience in the insurance sector overall, and each one of them has at least ten years of experience from the takaful sector. Interviewees were the high-level managers or retired high-level managers from takaful operators. Due to providing the anonymity of the interviewees', the name of the takaful companies have not been provided. Business Professionals numbered between B-1 to B- 5 that used as a reference for the following chapter.

Table 2: Profile of Business Professionals

\begin{tabular}{|l|l|l|l|}
\hline Number & Position & Experience & Education \\
\hline B-1 & General Manager & $\begin{array}{l}\text { 20 years of experience in takaful } \\
\text { business }\end{array}$ & BA Degree \\
\hline B-2 & $\begin{array}{l}\text { Ex-CEO, } \\
\text { Consultant }\end{array}$ & $\begin{array}{l}30 \text { years of experience in takaful } \\
\text { business }\end{array}$ & Master's Degree \\
\hline B-3 & $\begin{array}{l}\text { Ex-CEO, } \\
\text { Consultant }\end{array}$ & $\begin{array}{l}18 \text { years in insurance business, 11 } \\
\text { years in takaful business in both } \\
\text { general and family takaful. }\end{array}$ & Master's Degree \\
\hline B-4 & CEO & $\begin{array}{l}13 \text { years in insurance business, 10 } \\
\text { years in takaful business in both } \\
\text { general and family takaful }\end{array}$ & Master's Degree \\
\hline B-5 & CEO & $\begin{array}{l}20 \text { years in insurance business, 10 } \\
\text { years in family takaful business. }\end{array}$ & BA Degree \\
\hline
\end{tabular}

\subsection{Data Collection Method}

The interview method is a purposeful dialogue between two or more persons, requiring the interviewer to develop relationships, ask specific and clear questions to which the interviewee is prepared to reply, and listen carefully (Saunders et al., 2016, p. 572). Interview questions are designed based on the problems, challenges, and future expectations according to the literature review. Based on the previous studies, semi-structured questions were prepared for the interview. Semi-structured and in-depth interviews were used to collect qualitative analysis data (Saunders et al., 2016, p. 576). It is aimed to obtain some experience from Malaysian experts and transfer this to Turkey. For this reason, their opinion towards Turkish 
takaful industry is also asked. Before asking about their opinions towards Turkey, interviewees are informed about the Turkish takaful ecosystem for around 10 minutes.

Interviews conducted by using face to face interview technique. The primary benefit of faceto-face interviews is that by repeated or rephrasing the questions, the interviewer may modify the questions if appropriate, explain doubts, and ensure that the answers are well interpreted (Sekaran \& Bougie, 2016, p. 120). This technique enables a researcher to use a voice recording device, depending on the interviewee's approval. In this way, the researcher can transcribe the data to use in data analysis. During interviews, some brief notes are also taken to cross-check. Also, some answers were led to deeper questions that enabled to obtain more precise answers. Each interview took around 40 to 90 minutes. All interviews are recorded by permission of the interviewees, and they were informed that collected information would be kept confidentialinterview voice records used to verbatim transcription to analyse.

\subsection{Data Analysis Procedures}

Qualitative data analysis typically takes a longer time than quantitative analysis due to its nature of progress. It is not as easy as gathering statistical data and obtain the results by using some software programme. Every step of the qualitative analysis should be carefully taken because the analysis process is done manually. Even preparing data for analysis take quite some time. During the analysis, we have employed the following steps:

(1) Immediately before starting the data analysis process, voice records of the interviews listened carefully, and some notes were taken during the listening period. This step prepares the researcher for analysis and makes him familiar with the data. In this step, possible themes and codes are written down.

(2) The second step of the analysis was the preparation of the data, which is called transcription. Voice records of the interviews transcribed into the text verbatim. In this way, we have obtained the first draft of the interview transcriptions. This draft was a kind of word-by-word transcription of the interview, which had some errors and mistakes due to mistyping or failure of spoken language. In this step, possible codes and themes are clearer for the researcher.

(3) In the third step, voice records have listened again while controlling the first draft of the text. In this way, the text has been improved to provide a better understanding by changing some of the colloquial terms into proper written language. These procedures have been repeated for each interview. Thus, we have achieved a set of interview data from draft texts.

(4) The fourth step of the analysis is the importing of data to ATLAS.ti software programme. This software allows researchers to create codes, quotations, relationships between codes and data. Using qualitative data analysis software improves the creativity of the researcher. 
(5) Thematic coding is used based on the issues that have been discussed in the literature. According to codes, some thematic themes are created. These themes allowed the researcher to analyse the data systematically (Saunders et al., 2016).

(6) Coded data interpreted by using thematic themes.

\section{Findings and Discussion}

In this study, the phenomenological perspective has used, assuming "takaful" as our phenomenon. This phenomenon has been investigated by using the experience of business professionals and Shariah scholars. Through this technique, it is also aimed to obtain some essential suggestions for the Turkish takaful industry. For this reason, this section will be elaborated in two subsections. Firstly, we have created themes based on our codes to interpret the data more systematically. Secondly, lessons for Turkey will be explained, which adds value to qualitative analysis.

\subsection{Themes}

According to the qualitative analysis results, sixteen different codes can be used for classification. The literature survey and the research questions helped to develop these codes. Then they are categorised into six prominent themes that are created based on the interviews. The findings are discussed in accordance with these important themes.

\subsubsection{Public Awareness, Customer Preferences and Education}

Public awareness, customer perception, and education are three interrelated codes according to our findings. We have highlighted takaful agents' awareness in the following section. When we mention awareness under this theme, we refer to public awareness. It is found that the level of public awareness directly affects the customer perception towards takaful products. Additionally, education regarding the takaful system usually has a positive effect on the takaful business.

Malaysian customers' general awareness level about takaful is pretty satisfactory. A-2 asserted that there were various ways to access information today. For this reason, the general population is aware of takaful. A-2 supported this assumption by saying:

"... as I can see awareness as more than $60 \%$ and then the Muslims in Malaysia are now more sensitive whatever issue because they can get knowledge very easier nowadays, so they can get information from our website, any social media."

Takaful operators have been endeavouring to increase awareness in Malaysia by using different kinds of media tools such as TV advertisements, seminars, roadshows, exhibitions and public announcements. A-2 argued that "To increase the awareness so far this is not the main role of Shariah committee or Shariah council. But the takaful operator do their role in these matters..."

According to A-2, TOs should play a major role in increasing the awareness. A-1's answer also supported this argument, in which he said: “...it is not my role to promote, but we will contribute our effort in terms of promoting Islamic way of protecting our wealth, it is part of our religious duty as 
well." However, these Shariah scholars are aware of their responsibility from the Islamic point of view to increase the awareness towards financial operations to be conducted in line with Shariah.

Besides TOs, the government also helped increase the awareness about takaful using Friday prayer sermons (khutbah). B-2 described that event as follows: "I remember when we started takaful even we prepared the khutbah text, because we know our primary target is for the Muslims. So, we prepared the khutbah text for the Friday prayer and we distributed to the masjid, to the state, so that they distributed to all the masjid, so basically, the whole masjid in Malaysia is reading the text..." Nevertheless, A-3 did not find this practice adequate. A-3 complained about it because this practice was not implemented regularly, and she stated that "...it is once and not be enough, it must be quite regular. Because sometimes people are not aware that insurance is wrong..."

One of the current studies found that Friday sermons (khutbah) rarely cover topics related to Islamic finance in Turkey (Er \& Özdemir, 2019). Friday sermons are one the most important preaching foundation for Muslims which may reach millions of Muslims at a time. It is possible for Turkey to learn from Malaysia of this practice, which is also supported by that study (Er \& Özdemir, 2019).

On the other hand, practitioners were not satisfied with the market share ratio. B-1 and B-4 claimed that takaful awareness was not high among customers if the Malaysian insurance penetration rate was considered. A-4 supported this argument; however, B-5 criticised it because of the lack of awareness was not only for the takaful but also for the insurance system. B-5 also indicated the importance of the understanding of using the coverage against risks and the necessary financial planning by saying:

"What I think missing is that we need to go and change the attitude of Malaysians to be able to understand the importance of making sure that they protect themselves and their loved ones. Because I think this shows the social awareness that the public has not really understood."

This critical point of view reflects the importance of Islamic financial literacy. B-3 argued that although some people are aware of the importance of takaful or its differences from the conventional insurance, they are still not choosing takaful. His example also emphasises that it is an obligation for Muslims to select takaful, and he said that this problem could be solved with education. However, the education level in the rural areas is not as high as that in the cities as stated by B-1. Education plays a vital role in increasing the level of awareness of takaful. For this reason, takaful operators or associations should educate people not only in cities but also in rural areas. B-4 emphasised the importance of education in rural areas. This education process will affect customer perception of takaful products. B-4 indicated that awareness has a direct effect on the takaful penetration rate; once customers are aware that takaful is fully Shariah compliant, they will opt for takaful. This case emphasises the importance of education about financial products. B- 5 stated that: 
"I find it very sad to see Malaysians, we don't seem to give proper financial education to children, because we start when you are small, right? I think financial education should be started early to tell them what importance of saving money, the importance of making sure that you get yourself protected."

Again, this answer accentuates the importance of financial literacy that affects the preferences and the behaviour of customers.

It can be concluded that the awareness affects the takaful penetration and that it can be increased with the support of education. Nonetheless, the awareness is not the only determinant for takaful market penetration. Customers also have other preferences. For example, according to B-2, “... the customers are looking for a guaranty return, which is still difficult Islamically." This case is valid especially for the family takaful with saving options. However, aware Muslims would know there is no guaranteed return in Islamic products except rental income.

The surplus distribution is one of the salient features of the takaful system. This practice can be used as a motivator for potential customers to choose takaful products. This may also affect non-Muslim customers' choice as stated by B-2:

"...we should be consistently giving the surplus to the customers, because in most takaful we use surplus distribution as one of our strengths for the customers why they should come to takaful, for the Muslims probably that is not so important because they need to come to the Shariah-compliant. If you want to draw in the interest on the non-Muslims that is the only way I think, the surplus..."

Although, it is considered that Muslims opt for takaful products theoretically, some factors may affect their choices, such as price, or the cost of takaful products as stated by B-1. But there are two different opinions as explained by B-5 as follows:

"Some Muslims customers even though the takaful price is slightly higher, they are ok, they don't mind because they don't want to accept conventional insurance anymore. So those are customers that would buy takaful regardless of the price. There are those, however, are not yet there and they don't mind buying conventional because it is cheaper, so that is the choice that they have."

According to their answers, the price seems to be an esential determinant for the customers. However, some customers mind the principles of takaful over the price. On the contrary, A-4 argued that it is very less likely that people whose primary reason for choosing takaful is religion:

"...they have not primarily chosen it because it is religious, it is something Shariah-compliant, in fact, those who have said that I have chosen it because it is Shariah-compliant only 17\%. And that tells you that ultimately people will look at the features of the product whether make their expectation. It may be Islamic but not meeting the expectation, people will not choose it."

This finding leads us to investigate other reasons that motivate customers to choose takaful. Nevertheless, it is essential for a takaful product to meet the needs of the customers, otherwise the number of people who opt for takaful will be relatively low. 


\subsubsection{Regulation, Supervision, and the Role of the Government}

It is found that Malaysia is very supportive of TOs during its development process. B-2 expressed the relationship of TOs with the regulatory bodies as receptive and friendly. It is also found that being regulative-friendly helped the Malaysian takaful ecosystem to be better than other countries in terms of regulation and supervision. B-3 also remarked similar thoughts and said:

"...we have good, well-developed regulation for whole of that. But I think in the early stages we tend to just copy what the conventional has, instead of developing our own sharia framework or whatever, we tend to copy. That is kind of making a perception that insurance and takaful basically is one of the same."

Nevertheless, B-3 further indicated that developing its own framework is essential for the takaful ecosystem. Otherwise, adopting the same framework may cause a misconception that both takaful and the conventional insurance system are the same. However, the Malaysian authorities have already developed the proper regulation and governance framework for takaful operators. This case is also mentioned by B- 5 indicated that how Malaysian regulatory authorities well-regulated current frameworks for takaful ecosystem. Developing a new framework, offering new rules and regulations are not as easy as it sounds. B-4 asserted the challenges of implementing new regulations as follows:

"Not to say smooth but sometimes it is a bit difficult because we need to come up within the new products to be in line with whatever new regulation, but to me is every all operator will face this same thing so it still ok."

TOs have always been supported by the government and regulators, which helps them develop the takaful system properly. B-2 explained this as:

"I think the support from the government is continuing ever since. From day one when we started the government makes an announcement. It appears in the paper, in the newspaper that there is a takaful company established. In fact, the takaful is officiated by the prime minister even. And then the central bank is also very supportive..."

Having the support of the government is very important for the Malaysian takaful market as emphasised by A-4. The clear inference is that the government plays a crucial role in the development of the takaful industry. Their attitude towards TOs is helpful for the market, which is indicated by B-2 as: “... the central bank recognizes that takaful as a new industry must let the industry to grow first. And then when the industry is growing then you tighten your regulation..."

These answers reveal the importance of the approach of the regulatory and supervisory bodies for the development of the takaful system in Malaysia. Smooth and gradual steps help TOs to assort with regulations easier.

Besides that, regulatory bodies not only regulate the market but also pave the way forward for TOs as stated by B-5: "Bank Negara is pushing the industry to adopt new ways of distribution, the 
word is 'to disrupt the market', they are making it mandatory now for companies to offer online takaful insurance."

This initiative is the way to prepare TOs for the future. Therefore, regulatory and supervisory bodies are important for the progress of the takaful market, especially when it is at the early phase of the development. If a proper regulation does not exist, it may cause a crisis in the market as it has happened in Indonesia. B-1 stated this case as follows:

"If you don't have the government, the law to regulate the takaful operators, for the conventional insurance, they can even, to a certain extent, suelbring to the court the takaful operators because they can say that it is illegal, or you operate differently."

Meanwhile, Malaysia is an excellent example of appropriate regulation in the takaful market as stated by B-5.

\subsubsection{The Role of the Agencies}

Agencies play a major role in the insurance marketing. Approximately 80 percent of the insurance products have been sold through agencies in Turkey by the year of 2019 (TSB, 2019). In this study, the interviewees also indicated the critical role of the agencies for the Malaysian takaful ecosystem. For example, A-1 expressed the complexity of the takaful products and emphasised the importance of agents as follows:

"I think the agency is playing an important role in promoting the product. The success of a company in their sales, I think, lie heavily on the agency team."

Surprisingly, one of the first TOs in the market preferred to use direct marketing channels for their products, because the perception of the insurance agents was not good at that time. B-2 explained that experience as follows:

"Yes, they do not have a good image, the insurance agents. In fact, those who are working as insurance agents, they are also afraid or shy to say that 'I am an insurance agent'. Because the reputation is not so good. So, because of that, we don't use the agency as our primary distribution channel"

However, this practice did not last long. At present, the abovementioned TO has around 40,000 agents all around Malaysia, and the current progress of being a takaful agent is quite satisfactory, according to B-2. Agents are required to take 20 credit hours of training on takaful in a year. B-4 also specified 30 credit hours in a year for family takaful operators. Besides that, they need to pass a basic exam on takaful to become an agent. Also, one of the companies has another practice called "welcoming call" to improve their trust in agencies. B-4 explained the logic behind this call as making sure whether their agency made the right move for their customers. This kind of practice helps TOs make sure their agents are selling proper products according to the needs of their customers.

Although B-1 and B-2 held an opposite opinion, the awareness level of the takaful system and the products of the takaful agents is still unsatisfactory. B-5 asserted that agencies are not 
giving right the advice according to feedbacks. In the meantime, B-3 supported the argument by adding a lack of knowledge issue in agencies.

These arguments show that some of the companies just try to meet basic requirements. Differently, B-4 emphasised the training programme in their company to increase the awareness level of the takaful agents. However, this kind of attempt does not satisfy the Shariah scholars. It is found that all the Shariah scholars are not satisfied with the awareness and the knowledge level of the takaful agents as well. A-2 and A-4 said that according to his experience, takaful agents are not aware of the basic principles of takaful. A-3 thinks that it is the obligation of TOs to train their own agents. They should teach them to address major questions to their own Shariah boards. A lack of knowledge may cause irreversible effects. A3 supported this argument by saying:

"Some agencies may even see or make remarks which have an adverse effect on how takaful works, it makes remarks, it is same as insurance. This is kind of things that actually having, some negative connotation about takaful."

A-1 accentuated that training should be bidirectional. Because if the interlocutor is not receiving adequate knowledge, then there is a need to question the system. A-1 asserted this argument by saying: "... most of the people in Malaysia want to be agent for certain takaful operations because they want to get side income, so the purpose is for business, maybe we need to change their mindset and mentality."

These arguments also emphasise that if any $\mathrm{TO}$ is willing to increase their quality of agency services, they should consider whether their agent is doing this business full-time or not. Besides that, there is responsibility of the customer as well. Customers should read the required documents to learn about the products that they are interested.

Consequently, the awareness and the knowledge level of the takaful agents play a vital role in the takaful ecosystem. They are representatives of the TOs, thus, training the takaful agents is perceived as an essential requirement for TOs. Meanwhile, the mentality of the agents is also important in receiving and convey the message. Moreover, Marhanum, Nurdianawati Irwani, Siti Salwani, \& Saodah (2012), take the responsibility of the takaful agents one step further by adding the duty "to spread the objectives of takaful" to the society.

\subsubsection{Shariah Governance}

It is found that the Shariah committee is a vital component in the development of the takaful business. B-3 supported this argument by saying that "to have strong governance from the regulator side and also strong governance from the sharia side."

The Shariah governance system is another fundamental structure of the takaful ecosystem along with the regulatory authority. The Shariah committee has various roles in the takaful ecosystem. Firstly, this committee is the authority that authorised validation to the business operators from the Islamic points of view. B-2 described this situation as follows: 
"In the household goods, in the food industry, there is the halal stamp, but in takaful, in the financial market, there is no halal stamp, but the halal stamp is the Shariah committee because the financial market is so dynamic."

Secondly, having a Shariah committee increases the trust in the takaful company from the public. B-2 emphasised this case as:

"If you do not have a Shariah committee then how the market will have confidence fit in your company. In fact, in the Middle East, when I was in the Middle East, one of the sales propositions is the sharia committee, they are very proud to tell that 'Look at my sharia committee, they are very strict, they are very knowledgeable that is why you can trust my company more.' So, they use it as the marketing tools in fact."

It is clearly found that the Shariah committee can even be used for marketing in a way that it is considered as a factor of confidence for the takaful products.

Besides the Shariah committee, it is essential to have the highest authority in case of a disagreement in the market. B-2 emphasised that the SAC would provide a clear vision for the customers. The SAC is the supervisory authority for Shariah committees in the banking and insurance business. The SAC not only provides a Shariah framework but also regularly audits IFIs regarding Shariah issues. Takaful operators and Shariah scholars highly appreciate this mechanism. It is recognised that Malaysia is good at Shariah regulation and supervision, as A2 expressed this situation:

"Usually everything in Malaysia because it is really regulated market so everything related to sharia matters and must be tabled to the sharia committee, everything even the advertisement, the concept when they want to introduce new products..."

This excellent Shariah governance system owes its Shariah scholars a debt of gratitude. As indicated by B-5, "... you need of a forward-thinking Shariah committee with you that can also ensure that all of things that we do are sharia-compliant."

Malaysian Shariah scholars are mainly forward-thinking and that allows them to develop products and the system to meet their needs. B-1 also shared a similar thought on the issues of the scholars:

"Our Shariah Board members are more open minded compared to the Middle East. That is why started takaful first in Malaysia. They started much later because our Shariah scholars are more open minded. I mean, they are more business minded."

He also added the difficulty of working with Shariah scholars in the Middle east:

"Like in the Middle East, over there it is very difficult. The regulations are not business friendly."

This situation leads to another issue in the Shariah governance system - the globalisation of the rules and regulations. B-3 emphasised this case as follows: 
"I think the biggest issue more come from the Shariah perspective, not like Bank Negara they should be a global Shariah board. They need to invite all the renowned scholars that say okay, we accept this other model, have flexibility, and have the principle, that as long as you bought the principal, and they can implement this model everywhere as you want."

It is evident that having different opinions regarding Islamic financial products may cause problems in international operations. Also, it will increase the difficulty in standardisation. As indicated by B-3, the global level of the Shariah board is also required for business operations. Notwithstanding, the Accounting and Auditing Organization for Islamic Financial Institutions (AAOIFI) stands for this role, because its Shariah standards have been accepted by many other countries.

Besides the Shariah governance system, there are also some issues regarding Shariah. For example, B-2 complained about the phenomena that the society, especially the shareholders, did not have a high opinion of the Islamic financial rules. Instead, shareholders mostly target at their returns. B-2 said:

"... again, probably the challenge now is more towards creating the shareholders' value, the shareholders want to get a good return and so on. So, the importance of spreading the muamalah Shariah economics is not as important as what we want it to be, which I think it is still a lacking."

This situation can be discussed from different points of views. It can be said that shareholders are risking their money so that it is normal for them to seek profits. On the other hand, it is arguable that the Islamic principles and rules are as important as profit-makings for the operation of IFIs. However, it may hinder business operations if the rules are too strict.

The contracts identified for takaful operation has been widely discussed in the literature (Abdullah \& Fares, 2012; Billah, 2001; Habib \& Shaukat, 2016; Noordin, 2014). However, there are still unsettled discussions on the fundamental structure of the takaful contracts. Specifically, the issue of tabarru remains one of the most controversial issues in the takaful contracts (Azhar \& Badarulzaman, 2015; Mohd Noor \& Abdullah, 2009). In Malaysia, this issue has been settled, and they regard the contract as hibah rukba, as explained by A-1: "Previously they were discussing whether it is tabarru or not tabarru, whether it is hiba or not hiba, whether it is hiba, rukba, in Malaysia they have been looking at takaful as hiba."

However, this is not accepted by some other scholars, and it was offered to use waqf to create legal entity for takaful fund. A-1 continued:

"...like Indian continental, Pakistan and followed by South Africa because they have many Indian scholars in South Africa, they tend to look at takaful as a waqf, they say that we need to establish waqf in order to operate takaful, in order to create legal entity."

The main motivation for the creation of a waqf is to provide a legal entity status to the takaful fund as stated by A-4. In this way, the ownership issue will be solved. Currently, this model has mainly been applied in Pakistan. 
The other interviewee, A-3, also illustrated the importance of the ta'awun concept which differentiates takaful from the conventional insurance. A-3 said that ta'awun concept is the complementary of the tabarru' concept.

In short, the Shariah governance system is particularly essential for the takaful ecosystem and Malaysia has developed as one of the best examples in the world. Malaysian shariah governance system requires double layer Shariah auditing mechanisms. The first one is at the company level, which is done through the Shariah committees and the other one is at the government level, which is realised via the Shariah advisory council that audits the entire ecosystem. The business professionals and the Shariah scholars are found to be contented with the system. Although there are still some controversial issues regarding the Islamic values, those issues are not affecting the takaful business to be operated. Moreover, being openminded shariah scholar is highly appreciated by business professionals.

\subsubsection{Takaful Models}

It is found that Malaysia started its operations by using mudarabah model in the early period. B-2 explained that period as follows: "...when we started, also we use the mudarabah model, where we paid the surplus to the customer. At one stage, we paid even up to $25 \%$ return back to the customer, on the motor insurance, for example..."

As indicated by B-2, when TOs gave cashback to the customers, this situation helped them to be recognised. In this way, they promoted themselves distinctively from conventional insurance. Even though this practice enabled TOs to gain the trust of the customers, it was costly for them, as explained by B-2.

Gradually, TOs concerned about the sustainability of their operations; then they started to use the wakalah model. According to B-3, the wakalah model was chosen because takaful copied from their conventional counterpart, as he stated: "So again, back to my early statement up to the comfortness the regulator, that's why I said because we just copied from the conventional because conventional has agency, so we do agency which is wakalah."

Currently, the most common model in the world is the wakalah-mudarabah model, in other words, the hybrid model. Moreover, they implement this model with surplus sharing, which is named as the modified hybrid model. B-4 described this model as follows:

"we are using wakalah jualah mudarabah. If you are looking wakalah jualah mudarabah, why we are having that? The wakalah contract basically the contract is between the operator and the participant, basically participant appoint the takaful operator to manage the takaful business or to manage the takaful operation. Second, we have jualah contract. Jualah contract actually for the participant to share the profit surplus to the takaful operator, and we also have mudarabah model, where the mudarabah on the tabarru fund surplus we can share between participant and we share the profit or the tabarru investment between the participant and the operator."

Sharing surplus between TOs and participants is a controversial issue. Meanwhile, this practice is not permitted according to the AAOIFI takaful standard (no.26 par 5/5). However, 
A-2 argued that if there is a compromise between the customer and the TO, then, it should not be a problem from the Shariah perspective. Nonetheless, there is a practical problem emphasised by A-1 as follows:

"However, in practice, here in Malaysia as I said because the policy holders have no say at all, according to the practice, you like it you take it, you don't like it then you go or create your own takaful company. There is the problem. And all the operators will share, they say this is our portion and I want to take it."

This is a specifically essential point raised by A-1, which refers to the issue that who can make decisions for the participants on their behalf. In practice, normally the practitioners are not represented to make decisions. Instead, usually someone is chosen from the TO to represent the participants. Moreover, A-3 indicated the practicality and importance of the surplus sharing practice for practitioners to arrange unexpected costs.

Furthermore, A-4 indicated the importance of the underwriting process and practitioners considered the surplus due to their professional arrangement of the pricing. Then A- 4 said:

"Therefore, it is better to have that kind of buffer, the tool to support and protect the risk fund. Operationally many takaful operators justify this way."

Besides the wakalah model, there were other models being discussed with interviewees. Practically, the wakalah model has been considered as an exemplary model for the market. A1 explained this as: "...but in terms of the welfare of the policy holders, the participants, in terms of the pricing, the benefits that they get, I think cooperative model should be concerning more about the policy holders."

Although the cooperative model is considered one of the best model representing the essence of takaful, it is not really appreciated by the practitioners except for some countries. Moreover, A-3 argued that there is not much difference in practice within takaful models, as follows:

"I know that cooperative model success in Sudan, in Saudi Arabia they are saying that they are cooperative but when you really study their framework is not pure cooperative model, they are still quite similar with our model here"

A-4 supported this argument with his answer:

"We don't differ much from the commercial takaful, there is no big difference actually. The waqf model is seen as more clear in terms of the legal responsibilities and accountabilities."

Albeit he mentioned the differences of the waqf model, he also expressed the attractiveness of the hybrid model. A-4 said:

"3-4 years ago we developed two new model called the wadiah model, that models have not solved the issues, it only just solves the part of the issues, but we still have the most popular model which is wakala mudaraba model."

Consequently, the wakalah-mudarabah model seems to be the winner of the model selection due to its widespread usage and applicability in practice. 


\subsubsection{Market Practice: Challenges and Future Expectations}

Although the Malaysian takaful sector is relatively advanced according to B-2, it is still at the expansion phase. He also added a supportive argument for this claim: "One of the reasons why the takaful is growing up is that the central bank is very supportive" Besides that, A-4 mentioned other factors that stimulated the development of takaful in Malaysia as follows:

"...we have seen that the ecosystem of takaful which is supported by banking and Islamic capital market has also helped the growth of takaful in Malaysia."

A-1, A-2 and A-3 said there is still room for the takaful market to grow in Malaysia. Moreover,

B-3, B-4 and B-5, as practitioners, complained about the takaful penetration rate, which was around $14 \%$ at that time, and indicated the growth potential of the takaful market in Malaysia. B-4 also added that takaful will bypass conventional insurance in the future.

There were several challenges that the practitioners and Shariah scholars have faced in the past. Fortunately, those difficulties have been managed by their dedication and hard work. B5 indicated the difficulty of finding talented human resources as follows:

"...then develop your own internal capability, you are then forced to spend time to train your people, to develop them and it took some time, and it is not instant. But I can proudly say that if you put in the effort to develop your people and if you take a good care to your people, you will be able to develop your resources and I am proud to see the industry now has a lot more talents in the takaful space..."

Training more people was the primary solution for this challenge.

Another challenge was finding the retakaful operators who were practising their business in line with the Islamic finance principles. A-1 said:

"For example in the early days we allowed in general up to 45\% reinsurance and in some areas for example shipping maritime there is no takaful coverage, no retakaful coverage at all, because the risk is so huge, then we allowed for the takaful operators to go to the reinsurance if there is no coverage at all by retakaful company. So, nothing that cannot be solved theoretically."

It is important for a takaful operator to share its risk with a bigger operator. However, this was not possible at the early period of the takaful practice in Malaysia. A-3 supported this argument by indicating the insufficiency of capital adequacy and rating of the retakaful operators at early stages. For this reason, Shariah scholars have allowed TOs to use retakaful windows.

There is no doubt that investment is important for TOs to utilise idle funds. However, it was challenging to find proper investment tools at the beginning, as B-2 said:

"...in the past there are not that many Islamic investment instruments available in the market and then if there are a few, of course, we cannot risk our fund by putting them in very few instruments. We need to diversify the portfolio." 
This problem was solved with the government support by providing different types of investment tools. Currently, Malaysia is the owner of the one of the biggest sukuk markets in the world. B-2 stated as follows:

"These sukuks are not just the Shariah-complaint. They are good, well-rated sukuk with quite a reasonable dividend for the sukuk. So now for what I can see it is not that much problem anymore in terms of where to invest."

He mentioned the sukuk market in Malaysia not only by its size but also by the rating of the assets. This argument was also supported by B-5:

"I think the Malaysian stock exchange, the Malaysian banking system, bond market have responded very well. That is because in Malaysia there is a big push for Islamic finance. I think you will find that the situation may not be the same elsewhere."

The answers of B-3 and B-4 also reinforced these arguments. However, B-3 indicated a lack of stock securities in the market.

It is believed that the insurance business, as well as takaful, are moving forward to a new future. According to the requirements of a certain period, new products are designed and offered by companies with different motivations. B-3 explained their future vision as follows: "So, from death we move to living benefits. Now the next phase what is coming globally is we are talking about wellness, so from death to living benefits now the industry is on wellness."

It is expected that the takaful products will be more diversified and supportive of the healthy lifestyle, according to their new programme. In this way, customers will be careful about their health while enjoying their contractual benefits. Additionally, TOs are believed to have a lesser claim ratio, which will ease their risk management and claims operations. B-3 explained their programme regarding to this.

Another important expectation for the future is the digitalisation. B-4 explained that as follows: "We going to develop more distribution channel, not only depending on agency channel. We have also now bank channel, direct channel, online channel and all those."

B-1 also emphasised the digitalisation and the internet marketing will be the main agency for future operations due to the needs of the younger generations:

"...the younger generation, they prefer just take insurance through internet. So that's the future. A bit cheaper because we don't need to pay commissions to the agents."

In conclusion, the Malaysian takaful market is still considered in the growing phase and the future expectations of it are quite promising. Although the market faced some difficulties in the past, such as the inadequacy of human capital, investment tools and retakaful operators, they have managed well with the support of the government. In the future, it is believed that different types of products and marketing strategies will help takaful to lead the insurance market in Malaysia by the benefits of digitalisation. 


\subsubsection{Lessons for Turkey}

Figure 1 shows the relationship between the codes that are used for this study. There are two types of interviewees for the analysis, and they are named Practitioners and Shariah Scholars in Figure 1. This figure represents the interviewee's suggestions for the Turkish takaful market and the categories of those suggestions. It is apparent that the suggestions from both practitioners and Shariah scholars have mostly fallen into similar categories, except for the importance of the government's role and future expectations emphasised by the practitioners. This can be interpreted as practitioners, due to the nature of their job, are more businessminded and care about future operations and the easiness of the implementations of the regulations from the government, while the Shariah scholars mainly focus on the theoretical development of the takaful system.

Figure 1: Code Relationship Diagram

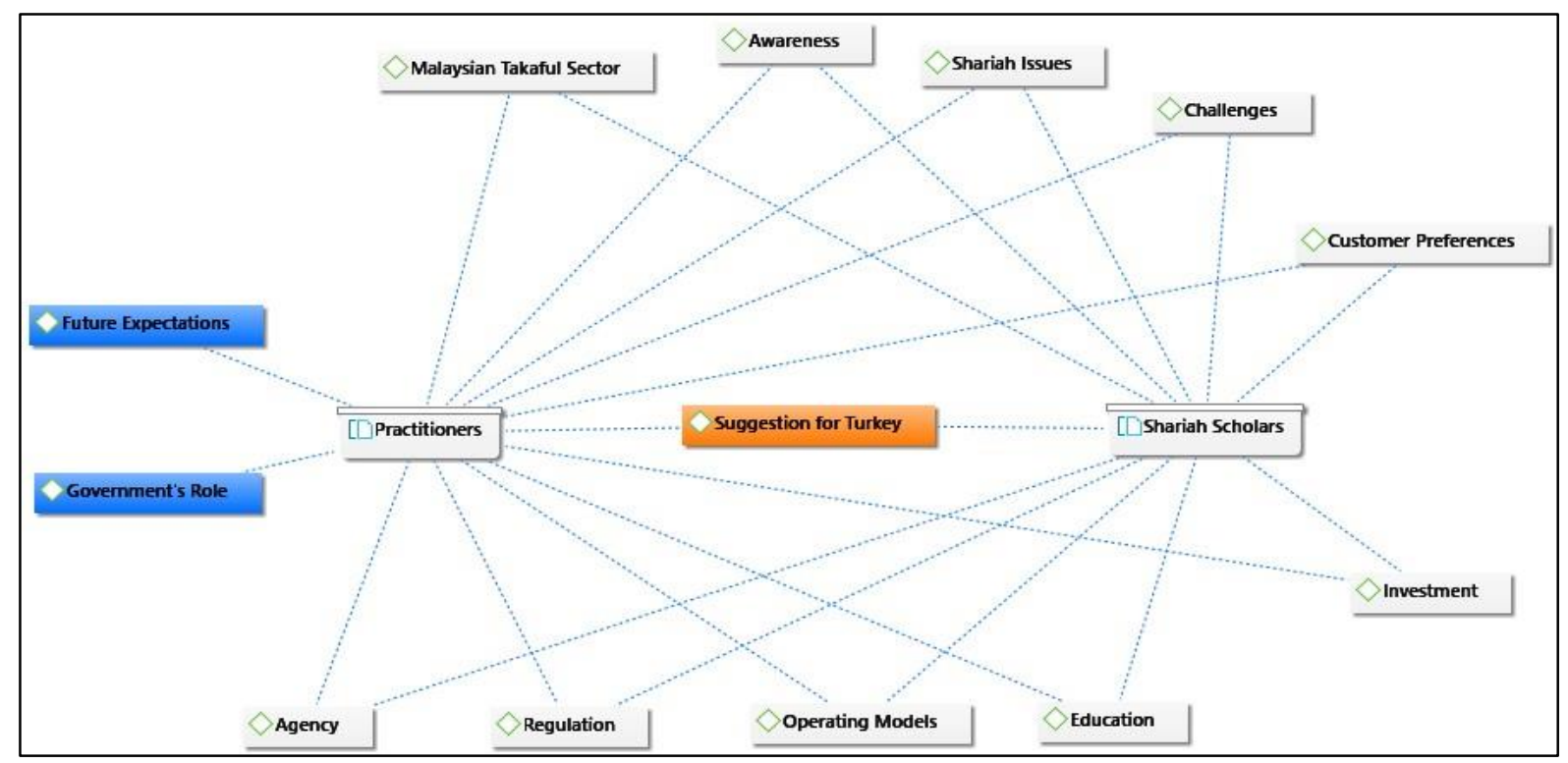

Turkey should follow small but solid steps to develop the takaful system. It is suggested that the takaful system should start with basic products. In this way, even conventional insurance companies would tend to approve their products. According to B-2, authorities should provide a list of approved companies that are offering takaful products. Then B-2 added that the regulation should follow up products and the Shariah governance system. A- 1 suggested that the Malaysian governance framework is a good example, and Turkey can adopt the Malaysian model. A-1 said:

"I believe we can share something from our experience especially from our governance part. We have a strong governance framework here in Malaysia, it is not from the bottom to top actually is the willingness and the initiative from the top as well, perhaps because people wants Islamic system, people want to see government to be Islamic, perhaps this also contribute to the best practice, but we can see clearly the steps taken by our central bank so they are willing and they are proactive doing things and to promote Islamic finance, they adopt Islamic finance as their needs and in their policy." 
As emphasised by A-1, a proactive role of the government and the regulatory authorities plays an important role in the development of the takaful ecosystem. B-3 also emphasised that the importance of the Malaysian experience would be beneficial for developing the Turkish takaful ecosystem. Contrary to A-1 and B-3, B-5 said:

"I don't necessary believe whatever works in Malaysia can work anywhere else. We must understand the local conditions, how a country operates and how the whole financial system in the country is organized and work within that system."

According to their answers, it can be summarised that it is possible for Turkey to learn from the Malaysian experience and adopt some of their practices. However, these practices require some changes and arrangements based on the idiosyncratic financial ecosystem of Turkey.

Additionally, the regulatory and the Shariah framework are two fundamental institutions to develop a proper takaful ecosystem in Turkey. A-4 said:

"We need to think if Turkey is really serious about this industry, they have to provide the so-called ecosystem for the takaful. And this ecosystem will begin first, with the legal framework, then with the regulatory framework, it can also with the sharia framework. I can say it is two important frameworks to develop, one is the legal, and one is the sharia."

This issue also has been mentioned by other interviewees. B-3 brought A-4's comments further and said:

"...first key steps like at the Turkey government or Turkey as whole want to really go in a big way establishing Islamic finance, which is the first to have proper regulation endorsed by the government. Have a proper regulation not just to be a subset in insurance, don't be a subset, it has separated regulation governing the takaful industry and also the central sharia body, like the one is Bank Negara."

As emphasised by B-3, the regulation for takaful should be separated, not combined with the conventional insurance. A-4 also indicated some of the rules should be covered in the regulation. Besides that, A-4 said "the central sharia committee, but at least there should be ruled and regulation governing the sharia committee at each and every takaful operator. Highlighting the rules and the responsibility, the remuneration and their appointment and the removal of the sharia committee. The sharia framework is very much needed."

As A-4 has expressed, the qualification and the Shariah governance system procedures should be designed and ruled accordingly. Nonetheless, A-3 argued that regulatory development should be gradually by saying:

"Sometimes too much regulation at the earlier stage can kill the market because of the over regulation. And that's why even in Malaysia it is terrifying we have more save regulation for the institution itself, you sell to your market, so we make sure that you are Shariah-compliant." 
Then A-3 explained this case with a metaphor by saying:

"...it is good to gradually put in the regulation by bit by bit until its sufficiently growing and you can put more regulation. It is just like a small kid you don't put so many rules to them but when they are bigger than you start more rules and more disciplines."

B-4 indicated that the risk of not having a proper regulation may cause exploitation in the market. Some may claim themselves as takaful without practising it. As it is clearly stated, without the regulation, the Shariah non-compliance may occur unwittingly. In addition, some companies may mislead the customers by using the names of the Shariah-compliant products without implementing the Islamic financial principles properly. B-1 insisted that allowing takaful windows may put the full-fledged takaful operators in a difficult situation:

"...you need to a develop a proper regulation. Although Indonesia is the largest Muslim country but its takaful is not much growing because the authority is not really strict. For example, they allow the conventional banks, conventional insurance to market takaful through windows, the windows like we did in the past. But they still allow so that we put full fledge takaful operators. It is very difficult to compete, unlike here. For takaful operators, they must have full fledge takaful operation. They shouldn't allow some windows, some full fledge. Otherwise, it is difficult to compete."

Considering the above opinions, it is evident that the Shariah governance system is so important that it is fundamental and obligatory for the takaful ecosystem to implement it. However, implementing a comprehensive structure can be difficult at the beginning phase. For this reason, A-3 indicated that the Shariah governance system could be developed parallel to the business development by saying:

"Proportional means the regardless of your Shariah governance, if your business is so small you don't expect to need one of officer for Shariah review, another officer for Shariah audit, and another officer for risk function. So maybe just one officer is enough to look at all the aspects because your operation is very small but if your business grows bigger maybe you need to get more officers."

Besides the governance system, A-4 illustrated other important aspects of the takaful ecosystem by saying:

“...you are need of supporters, supporting agencies such as you need to have human capital in all aspects. You need to have more actuaries who understand the technicalities on the takaful. You need to have qualified and underwriters who understand the between underwriting takaful products, you need to have claim managers, so this is all this and the training part. That market is in need of good training industry to be trained and trained and trained because the market is changing drastically at the demand of the market."

A-4 especially indicated the importance of the human capital. Moreover, B- 5 indicated that while training or education people, it is also necessary to educate both the conventional insurance and takaful by saying: 
"...it's best for someone to be able to go both the conventional spectrum and the takaful spectrum and then arrive at the place where they understand both and that's why there would be of better value. So I am keen in developing takaful talents, but I also tell my takaful talents to understand the conventional system, because for you to be an expert in Malaysia you must understand both. You can't do just one. It could be the same in Turkey as well because you also run both systems."

B-5 expressed that this situation is especially true for countries like Turkey, where both the conventional and takaful companies work in the same insurance market. Furthermore, A-3 has mentioned, the awareness can be increased by education. It can be interpreted in this way: the sooner you educate your future customers, the better results you may have.

Lasty, investment tools were also mentioned in the interviews. They suggested that the takaful ecosystem requires Islamic investment tools to be appropriately developed. B-1 said:

"...they need to promote sukuk otherwise it will be very difficult for the fund to be invested in Shariah fund. Then you need to be regulated same like the Securities Commission here. So that is the first step that we need to do - get the regulations."

Without the necessary investment tools, it will not be easy for TOs to grow. On the other hand, A-4 indicated some other products that can be developed in the future parallel to the growth of the takaful ecosystem in Turkey. A-4 said:

"So that is the investments you need you have Shariah-compliant assets, on the marketing you need create more distribution channels such as bank and takaful, and on also for so-called financial inclusion you need also think about micro-takaful, the whole ways where people have really seen you are working on financial inclusion so need to have macro-takaful as well."

In brief, interviewees firstly indicated the importance of regulation and the Shariah governance system as a suggestion for the development of takaful to Turkey. Meanwhile, it is also advised that this development should be done gradually regarding the needs of the market. They also mentioned the risks of not having the regulation and the Shariah governance. Additionally, they have expressed the importance of the human capital. With the growth of the market, more qualified people will be needed in the market. Moreover, it is emphasized that Shariah compliant investment tools are a must for the takaful operator. Finally, different types of products have been suggested, for example, Turkey can develop microtakaful products to increase the financial inclusion in the future

\section{Conclusion}

In this paper, it has adopted a phenomenological perspective, assuming takaful as our phenomenon. This phenomenon has been investigated by examining the experiences of the business professionals and the Shariah scholars from Malaysia to develop the takaful system in Turkey.

It is found that awareness has a direct effect on takaful penetration which can be increased by proper education. Islamic financial literacy level helps not only the takaful market but also the 
whole IFIs. Agencies' knowledge and awareness are very important for takaful operators because they are those who lead the customers. Since it has been found that some agencies may mislead the customers about the takaful system due to the deficiency of knowledge, it is a must for a TO to train agents of fundamental principles about takaful.

Although agencies are very important for the takaful ecosystem, it has been indicated in the interviews that takaful operations are being affected by the current uptrend of the technology like other financial operations. This uptrend makes internet marketing more and more popular and necessary, especially for the fact that the Gen-Y and the Gen-Z are hand in glove with the technology. For this reason, they tend to spend less time on conventional ways of consuming. This finding may light the way for the Turkish TOs for their future marketing decisions.

In terms of the regulation and supervision bodies, they are very well organised in Malaysia and takaful operators are supervised in both Shariah and technical perspectives. Centralised Shariah governance bodies and unified regulations make it easier for practitioners and regulators to proceed with business. Meanwhile, takaful operators are supported by the government and the regulatory bodies. These are one of the main reasons that help the takaful market grow in Malaysia. It is possible for the Turkish regulators to implement these steps for further development of the Turkish takaful ecosystem.

The Shariah committee is very important for takaful business. This committee has a different kind of contribution to the operations. Firstly, if you have a Shariah committee, it will increase the customers' trust in the company. This is a solid proof that your operations are Shariah compliant. In other words, if a TO's committee consists of acknowledged people in Shariah, it can be used as a promotion for TO's operations. A strong Shariah committee can attract more customers who seek for trustworthy Islamic insurance products. It can be said that the Shariah governance system practised in Malaysia is strong and efficient. This can be found in the appreciation of the Shariah governance system uttered by the Malaysian Shariah scholars and practitioners in the interviews. Therefore, it is advised for Turkey to benefit from their experience. However, it might require some adjustments before implementing this Shariah governance system into practise due to the idiosyncratic features of Turkey. Moreover, it is very important to notice that without the government support, the takaful ecosystem may not grow as healthily as in Malaysia.

In short, the findings of this study are expected to help practitioners, regulators and Shariah scholars to develop a proper ecosystem for takaful in Turkey. It is recommended that starting from developing a proper regulation and Shariah governance system helps the further development to be more tangible. Additionally, TOs need to focus on talent development if they are willing to increase their market penetration. In the meantime, they should invest in increase of the takaful literacy by educating the youth as early as possible. This is an initial and comprehensive study; further studies can focus on each theme separately for investigation. 


\section{References}

Abdullah, N. I., \& Fares, D. (2012). Applications of Malaysia Deposit Insurance Corporation (MDIC) To Takaful Operators: An Analysis from the Shariah Advisors' Perspective. Information Management and Business Review, 4(12), 615-624.

Aksoy, M. A. (2018). Türkiye'de Katılım Sigortacılığı. Ankara Hacı Baram Veli Üniversitesi Hukuk Fakültesi Dergisi, XXII(2), 3-36.

Alhabshi, S. O. (2017). Challenges for the Takaful Industry. In M. Ariff \& S. Mohamad (Eds.), Islamic Wealth Management Theory and Practice (pp. 249-265). Edward Elgar. https://doi.org/10.4337/9781786439390.00023

Ali, E. R. A. E., \& Odierno, H. S. P. (2008). Essential Guide to Takaful (Islamic Insurance) (1st ed.). CERT Publication.

Aslan, H. (2015). Türkiye'de Tekafül (İslami Sigorta) Uygulamaları: Problemler ve Çözüm Önerileri. International Journal of Islamic Economics and Finance Studies, 1(1), 93-117.

Aslan, H. (2017). Tekâfül Uygulamalarının Güncel Sorunları: Türkiye Piyasası İçin Bir Değerlendirme. In S. Kaya, F. Yardımcoğlu, \& H. Aslan (Eds.), Tekâfül: Teori ve Uygulama (pp. 153-172). Ensar Neşriyat.

Aslan, H., \& Durmuş, M. E. (2016). İslami Sigortacılık (Tekafül): Yöneticilerin Perspektifinden Türkiye Uygulaması. In Ö. Karaoğlu, S. Kaya, F. Yardımcıŏ̆lu, \& H. Aslan (Eds.), International Congress on Islamic Economics and Finance (Issue Vol 3: "Islamic Finance: Sukuk and Takaful," pp. 17-29). Beşiz Yayınları. http://www.isefam.sakarya.edu.tr/wpcontent/uploads/2017/10/Volume-3.pdf

Ayedh, A. M., \& Echchabi, A. (2015). Shari'ah supervision in the Yemeni Islamic banks: a qualitative survey. Qualitative Research in Financial Markets, 7(2), 159-172. https://doi.org/10.1108/QRFM-06-2014-0017

Azhar, A., \& Badarulzaman, M. H. (2015). The Practice of Hibah in Takaful Institutions : A Case Study in Takaful Ikhlas Sdn. Bhd. The Journal of Muamalat and Islamic Finance Research, 12(2), 41-54.

Berkem, Z. (2014). Effective Supervision of Islamic Insurance According to Malaysian Experience (1984-2012). International Journal of Social Economics, 41(12), 1220-1242. https://doi.org/10.1108/IJSE-08-2013-0182

Billah, M. M. (2001). Sources of Law Affecting Takaful (Islamic Insurance). International Journal of Islamic Financial Services, 2(4).

Burton, B. (2007). Qualitative Research in Finance - Pedigree and Renaissance. Studies in Economics and Finance, 24(1), 5-12. https://doi.org/10.1108/10867370710737355

Çalık, A. (2014). Katılım Bankalarında Sigorta Uygulamaları ve Tekâfül Sigorta Sistemi. Finans Politik E Ekonomik Yorumlar, 51(587), 95-106.

Christensen, L. B., Johnson, R. B., \& Turner, L. A. (2015). Research Methods, Design and Analysis (12th ed.). Pearson.

COMCEC. (2016). National and Global Islamic Financial Architecture: Problems and Possible Solutions for the OIC Member Countries (Issue October). http://ebook.comcec.org/Kutuphane/Icerik/Yayinlar/Analitik_Calismalar/Mali_Isbirligi 
/Toplanti7/index.html

COMCEC. (2019). Improving the Takaful Sector In Islamic Countries.

Dalgın, N. (1994). İslam Hukukuna Göre Sigorta. Ondokuz Mayıs University.

Dalgın, N. (2003). İslam Hukuku Açısından Karşılıklı Sigortalar. İslami Araştırmalar Dergisi, $16(4), 615-629$.

Demir, F. (2002). Sigorta ('Âkıle Müessesesi ve Süftece Muamelesi Işığında Bir Tedkik). Ankara Üniversitesi İlahiyat Fakültesi Dergisi, XLIII(2), 169-200. http://ktp2.isam.org.tr/detayilhmklzt.php?navdil=tr\&midno=10475625\&Konu=İslâm+H ukuku

Echchabi, A., \& Abd Aziz, H. (2014). Shari'ah Issues in Islamic Banking: A Qualitative Survey in Malaysia. Qualitative Research in Financial Markets, 6(2), 198-210. https://doi.org/10.1108/QRFM-12-2012-0035

Edmonds, W. A., \& Kennedy, T. D. (2017). An Applied Guide to Research Designs: Quantitative, Qualitative, and Mixed Methods (Second). SAGE.

Er, A. İ., \& Özdemir, M. (2019). İslam İktisadı Söylemlerinin Cuma Hutbelerindeki Yeri: İstanbul İli Örneği. Pesa Uluslararası Sosyal Araştırmalar Dergisi, 5(2), 150-169. https://doi.org/10.25272/j.2149-8385.2019.5.2.09

Faisal Nazir Hussain, \& Noor, A. M. (2018). An Assessment of Customer's Preferences on The Selection of Takaful Over Conventional: A Case of Saudi Arabia. Tazkia Islamic Finance and Business Review, 12(1), 33-60.

Guest, G., Bunce, A., \& Johnson, L. (2006). How Many Interviews Are Enough?: An Experiment with Data Saturation and Variability. Field Methods, 18(1), 59-82. https://doi.org/10.1177/1525822X05279903

Habib, F., \& Shaukat, M. (2016). Shariah Appraisal of the Takaful Model Based on "Tabarru" (Donation). Journal of Islamic Banking \& Finance, 33(3), 65-83.

Hacak, H. (2017). İslami Sigorta (Tekâfül) Ticari Sigortadan Farklı Mıdır? In S. Kaya, F. Yardımcoğlu, \& H. Aslan (Eds.), Tekâfül: Teori ve Uygulama (pp. 93-110). Ensar Neşriyat.

Ismail, E., \& Alhabshi, S. O. (2017). Takaful. In B. Abdul Hamid, M. H. Ibrahim, \& S. Kamarudin (Eds.), Islamic Finance the New Normal (pp. 321-358). Pearson.

Jaiyeoba, H. B., \& Haron, R. (2016). A Qualitative Inquiry into the Investment Decision Behaviour of the Malaysian Stock Market Investors. Qualitative Research in Financial Markets, 8(3), 246-267. https://doi.org/10.1108/QRFM-07-2015-0027

Kaczynski, D., Salmona, M., \& Smith, T. (2014). Qualitative research in finance. Australian Journal of Management, 39(1), 127-135. https://doi.org/10.1177/0312896212469611

Laçinbala, Y., \& Ünsal, H. (2019). Katılım Sigortacılığında (Tekafülde) Pencere Sisteminin Değerlendirilmesi. Sosyoekonomi, 27(42), 181-202. https://doi.org/10.17233/sosyoekonomi.2019.04.10

Leavy, P. (2017). Research Design: Quantitative, Qualitative, Mixed Methods, Arts-Based, and Community-Based Participatory Research Approaches. The Guilfod Press.

Loke Ke Wei, K., \& Mohd Thas Thaker, H. (2017). A Qualitative Inquiry into Islamic Home 
Financing: Evidence from Malaysia. Qualitative Research in Financial Markets, 9(2), 147167. https://doi.org/10.1108/QRFM-07-2016-0020

Marhanum, C. M. S., Nurdianawati Irwani, A., Siti Salwani, R., \& Saodah, W. (2012). Takaful Agents' Roles in Accordance with the Quran and Sunnah. Global Journal Al-Thaqafah, 2(2), 41-45. https://doi.org/10.7187/GJAT212012.02.02

Md Zabri, M. Z., \& Mohammed, M. O. (2018). Qualitative Validation of a Financially Affordable Islamic Home Financing Model. ISRA International Journal of Islamic Finance, 10(2), 143-161. https://doi.org/10.1108/JJIF-08-2017-0023

Merriam, S. B., \& Tisdell, E. J. (2016). Qualitative Research A Guide to Design and Implementation (Fourth). Jossey Bass.

Mohammed, N., Binti, N., Nor, M., Kamil, N. M., \& Nor, N. B. M. (2014). Factors Influencing the Choice of Takaful Over Conventional Insurance : The Case of Malaysia. Journal of Islamic Finance, 3(2), 1-14.

Mohd Fauzi, P. N. F., \& Abdul Rashid, K. (2014). The Methods in Assessing Takaful Claims for Construction Works Loss and Their Legitimacy From the Shariah Perspectives. The 2nd IIUM - Kyoto University Research Colloquium Shari'ah Compliance Issues in Construction, 8 May 2014, 601-622.

Mohd Noor, A., \& Abdullah, M. A. (2009). Takaful (Islamic Insurance) Benefit: Ownership and Distribution Issues in Malaysia. Journal of Islamic Economics, Banking and Finance, 5(3), 3548.

Noordin, K. (2014). The Implementation of Tabbaru' and Ta'awun Contracts in the Takaful Models. In A. Ab Rahman, W. M. Wan Ahmad, \& S. Mohamad (Eds.), Islamic Economics, Banking and Finance: Concepts and Critical Issues. (pp. 91-112). Pearson Education Asia.

Noordin, K., \& Fares, D. (2017). Issues and Challenges in Introducing Islamic Insurance (Takaful) into the Algerian Financial Market: Lessons from Malaysia. In S. K. Ab. Manan, F. Abd Rahman, \& M. Sahri (Eds.), Contemporary Issues and Development in the Global Halal Industry (pp. 359-369). Springer. https://doi.org/10.1007/978-981-10-1452-9

Ölçen, O. (2014). Tekaful Sigortacılık Sistemi. İZU Sosyal Bilimler Dergisi, 2(5), 169-196.

Othman, A., Sari, N. M., Alhabshi, S. O., \& Mirakhor, A. (2017). Macroeconomic Policy and Islamic Finance in Malaysia (1st ed.). Palgrave Macmillan.

Özdemir, M., \& Aslan, H. (2018). The Political Economy of the Transformation of Islamic Finance in Turkey. https://www.setav.org/en/report-the-political-economy-of-the-transformationof-islamic-finance-in-turkey/

Rahman, Z. A., \& Redzuan, H. (2009). Takaful The 21st Century Insurance Innovation (1st ed.). McGraw-Hill.

Ritchie, J., \& Lewis, J. (2003). The Foundations of Qualitative Research. In J. Ritchie \& J. Lewis (Eds.), Qualitative research practice: A guide for social science students and researchers. SAGE. https://doi.org/10.4135/9781452230108

Sakti, M. R. P., Syahid, A., Tareq, M. A., \& Mohd Mahdzir, A. (2016). Shari'ah Issues, Challenges, and Prospects for Islamic Derivatives: A Qualitative Study. Qualitative Research in Financial Markets, 8(2), 168-190. https://doi.org/10.1108/QRFM-06-2015-0024 
Salmona, M., Kaczynski, D., \& Smith, T. (2015). Qualitative theory in finance: Theory into practice. Australian Journal of Management, 40(3), 403-413. https://doi.org/10.1177/0312896214536204

Saunders, M., Lewis, P., \& Thornhill, A. (2016). Research Methods For Business Students (7th ed.). Pearson.

Sekaran, U., \& Bougie, R. (2016). Research Methods for Business: A Skill-Building Approach (7th Editio). John Wiley \& Sons. https://doi.org/10.13140/RG.2.1.1419.3126

TSB. (2019). Official Insurance Statistics. https://www.tsb.org.tr/resmiistatistikler.aspx?pageID=909

Ünalan, A. (2008). İslâm Hukukunda Muvâlât Akdi Ve Sigorta Açisindan Değerlendirilmesi. Dicle Üniversitesi İlahiyat Fakültesi Dergisi, X(1), 1-17.

Ünlü, U. (2018). Tekafül Sigortası Kapsamında Sigortalılarca Ödenen Primlerin İadesi. Mali Çözüm, 28(150), 149-155.

Ustaoğlu, M. (2014). Alternatif faizsiz sigortacılık uygulamaları ve gelir seviyesine göre kamu bilincinin değerlendirilmesi: Ampirik analiz. Siyaset, Ekonomi ve Yönetim Araştırmaları Dergisi, 2(2), 109-130.

Üstün, Y. (2014). Sïgorta, tekafül ve kooperatif Sigortacılığı. Karınca Dergisi, 80(927), 1-12.

World Bank, \& IDGB. (2016). Global Report on Islamic Finance: Islamic Finance: A Catalyst for Shared Prosperity. https://doi.org/10.1596/978-1-4648-0926-2

Yas, M., Aslan, H., \& Ozdemir, M. (2018). Modern History of Islamic Finance and a Strategic Roadmap for Its Development in Turkey. In A. F. Aysan, M. Babacan, N. Gur, \& H. Karahan (Eds.), Turkish Economy: Between Middle Income Trap and High Income Status (pp. 213-238). Springer International Publishing. https://doi.org/10.1007/978-3-319-703800_10

Yıldırım, İ. (2014). Tekafül (İslami) Sigortacılık Sisteminin Dünyadaki Gelişimi ve Türkiye'de Uygulanabilirliği. Organizasyon ve Yönetim Bilimleri Dergisi, 6(2), 49-58.

Yılmaz, A. (1997). İslam Hukuku Açısından Sigorta. Harran Üniversitesi İlahiyat Fakültesi Dergisi, 3, 133-162. 